\title{
ORIGINS OF PLEXUS BRACHIAL IN Iguana iguana iguana
}

\author{
ORIGENS DO PLEXO BRAQUIAL DA Iguana iguana iguana
}

\author{
Rozana Cristina ARANTES ${ }^{1}$; Frederico Ozanam CARNEIRO E SILVA ${ }^{2}$; \\ Ana Kelen Felipe LIMA ${ }^{1}$; Maria de Jesus Veloso SOARES ${ }^{1}$; Hassen JERBI ${ }^{3}$ \\ 1. Course of Veterinary Medicine of Veterinarian Medical College of Tocantins Federal University of Campus Araguaína, TO, Brazil. \\ rozanacristina.arantes@gmail.com; 2. Course of Veterinary Medicine of Veterinarian Medical College, Federal University of \\ Uberlândia, Uberlândia, MG, Brazil. 3. Ecole Vétérinaire Sidi Thabet, Tunisie
}

\begin{abstract}
ASTRACT: This paper aims to describe the origin of the brachial plexus of 12 iguanas, male and female, which were donated already dead by the Wild Animal Screening Center and Independent Company of Highway and Environmental Police of the Araguaína, Tocantins State, to Veterinary Anatomy Laboratory of Federal University of Tocantins, Araguaína campus These animals were fixed by intramuscular injections of aqueous $10 \%$ formalin. It was made a parallel incision to dorsal midline from the skull to the caudal ribs. It was pulled all the epiaxial muscles eight ribs, the periosteum, exposing and individualizing the ventral rami of spinal nerves that make up the brachial plexus. The ventral rami of spinal nerves $\mathrm{C} 6, \mathrm{C} 7, \mathrm{C} 8, \mathrm{~T} 1$ and $\mathrm{T} 2$ form the brachial plexus in 12 iguanas. In $41.6 \%$ of cases, the branches involved were $\mathrm{C} 6, \mathrm{C} 7, \mathrm{C} 8$ and $\mathrm{T} 1$; in $33.4 \%$, the branches $\mathrm{C} 6, \mathrm{C} 7, \mathrm{C} 8, \mathrm{~T} 1$ and $\mathrm{T} 2 ; 16.6 \%$ the branches $\mathrm{C} 7, \mathrm{C} 8, \mathrm{~T} 1$ and $\mathrm{T} 2$ and in $8.4 \%$, the branches $\mathrm{C} 7, \mathrm{C} 8$ and $\mathrm{T} 1$. The branches ventral $\mathrm{C} 7, \mathrm{C} 8$ and $\mathrm{T} 1$ formed three trunks and $\mathrm{C} 6$ and $\mathrm{T} 2$, when present, consisted of nervous fillet. There was variation in number of vertebrae in Iguana iguana iguana which caused oscillations in anastomoses, that constitute the nerves of brachial plexus. The axillary, subscapular, cutaneous, pectoral, coracobrachialis, radial, median, ulnar, thoracodorsal nerves are the main nerves that constitute the brachial plexus in iguanas.
\end{abstract}

KEYWORDS: Forelimb. Iguana iguana iguana. Peripheral nervous system. Spinal nerve.

\section{INTRODUCTION}

There are 10,032 of reptiles species in world. In Brazil there were identified 760 species, belonging to 718 Squamata order, which includes snakes, lizards and amphisbaenians, 36 turtles and six alligators. Every year there are new species cataloged (SOUZA et al., 2013; BENÍCIO et al., 2015). They inhabit the most different and diverse environments, especially warm areas (SOUZA et al., 2013).

Iguana iguana iguana is a lizard of Iguanidae Family, and its body has spines along the back and tail looking like thorns, and also a large, round scaly under the eardrums and a gular fold well developed. The iguana displays varied colors, usually young ones have an vivid green color, while in adults, diversifies color and may have diffuse dark vertical stripes on the body and tail (ANDRADE, 2009).

In vertebrates, the ventral rami of spinal nerves, located in regions of deployments of forelimbs and adjacencies constitutes the nerves that form the brachial plexus. The spinal nerves are named according to position that they occupy in the spine. The first cervical spinal nerve, $\mathrm{C} 1$, emerges lateral vertebral foramen atlas', while the second spinal nerve, $\mathrm{C} 2$, emerges from the intervertebral foramen, located between the first cervical vertebrae, atlas, and the second cervical vertebrae, the axis (SCAVONE et al., 2008).

In Agama agama and Chalarodon madagascariensis, brachial plexus originates in the ventral branches of spinal nerves $6,7,8,9$ and 10 (RENOUS-LÉCURU, 1972). The brachial plexus, in birds, begins from the ventral rami of spinal nerves 12, 13, 14, 15 and 16 (BAUMEL, 1986). The brachial plexus, in Ornithorhynchus anatinus, corresponds to ventral branches of the cervical spinal nerves C4, C5, C6, C7, C8, thoracic spinal nerves $\mathrm{T} 1$ and $\mathrm{T} 2$, and in Tachyglossus aculeatus comprises the ventral branches of the spinal nerves C3, C4, C5, C6, C7, C8, T1 and T2 (KOIZUMI; SAKAI, 1997).

The brachial plexus, in crocodiles, originates in the ventral rami of spinal nerves 7, 8, 9, 10 and 11 (SUZUKI; HAYASHI, 2010). In Saimiri, the ventral rami of spinal nerves C4, C5, C6, C7, C8 and T1 equivalent to brachial plexus (ARAÚJO et al., 2012). The brachial plexus, in anteater, comprises the ventral branches of spinal nerves C5, C6, C7, C8 and T1 (CRUZ et al., 2012). In Hippopotamus amphibius, the brachial plexus originates from ventral rami of spinal nerves C5, C6, C7 and T1 (YOSHITOMI et al., 2012). In Falco columbarius, the brachial plexus corresponds to the ventral rami of spinal nerves C10, C11, C12, C13, T1 and T2 (CEVIK-DEMIRKAN, 2014). 
The knowledge about Nervous System of reptiles is deficient, requiring research with emphasis on descriptive anatomy, histological and pathological these animals. This research aimed to describe the origins of iguana brachial plexus in order to be a compilation of Nervous System of species, with application in clinical and surgery practice.

\section{MATERIAL AND METHODS}

The Wild Animal Screening Center and Independent Company Highway and Environmental of Military Police donated 12 dead iguanas, eight males and four females, from different ages and length ranging from 0.6 to 1.25 meters, to Veterinary Anatomy Laboratory of Federal University of Tocantins, situated at Araguaína of Tocantins State.

These animals were fixed in $10 \%$ formalin solution with intramuscular injections. Following that, a parallel incision to dorsal midline from skull to last rib was made, and all epiaxial muscles, eight ribs and periosteum were removed, exposing and individualizing the spinous processes for counting the vertebrae and identification of ventral rami of corresponding spinal nerves to the nerves that compose the brachial plexus. It was made a statistical analysis using the arithmetic average, schemed and photographed and the nomenclature is according to Baumel et al. (1993). The use of dead animals is consistent with Normative Instruction number 154/2007 of IBAMA and Law No. 11,794 / 2008.

\section{RESULTS}

There are five iguanas with eight cervical vertebrae, 14 thoracic vertebrae, two sacral and a variable number of caudal vertebrae and seven iguanas with eight cervical vertebrae, 15 thoracic vertebrae, two sacral and various number of caudal vertebrae. The ventral rami of spinal nerves $\mathrm{C} 6, \mathrm{C} 7$, $\mathrm{C} 8, \mathrm{~T} 1$ and $\mathrm{T} 2$ form the brachial plexus of 12 iguanas and exhibit symmetry between the antimeres, consisting: in $41.6 \%$ of cases by ventral rami of spinal nerves $\mathrm{C} 6, \mathrm{C} 7, \mathrm{C} 8$ and $\mathrm{T} 1$; in $33.4 \%$ of cases by ventral rami of spinal nerves $\mathrm{C} 6, \mathrm{C} 7$, $\mathrm{C} 8, \mathrm{~T} 1$ and $\mathrm{T} 2$; in $16.6 \%$ of cases by ventral rami of spinal nerves $\mathrm{C} 7, \mathrm{C} 8, \mathrm{~T} 1$ and $\mathrm{T} 2$; and in $8.4 \%$ of cases by ventral rami of spinal nerves $\mathrm{C} 7, \mathrm{C} 8$ and T1. There are formed three trunks: cranial trunk: the ventral rami of spinal nerve $\mathrm{C} 7$; medium trunk: the ventral rami of spinal nerve $\mathrm{C} 8$ and the caudal trunk: the ventral rami of spinal nerve T1. And when presents, the ventral rami of spinal nerves C6 and $\mathrm{T} 2$ consist of nervous fillet.

There are several anastomoses between the ventral rami of cervical spinal nerves and ventral rami of spinal thoracic nerves in the formation of nerves that innervate the forelimbs, as shown in Table 1. In Figure 1, schematic representation of origin and distribution of brachial plexus nerves in one Iguana iguana iguana.

Table 1. Origins of main nerves that compose the brachial plexus in Iguana iguana iguana.

\begin{tabular}{ll}
\multicolumn{1}{c}{ Nerve } & \multicolumn{1}{c}{ Origin } \\
\hline Subscapular & Ventral branch of spinal nerve C6 or C6 and C7 \\
Cutaneous & Ventral branch of spinal nerve C6 and C7 or C8 \\
Pectoral & Ventral branch of spinal nerve C7 or C8 and T1 \\
Coracobrachialis & Ventral branch of spinal nerve C8, T1 and T2 \\
Axillary & Ventral branch of spinal nerve C6 and C7 or C7 and C8 \\
Radial & Ventral branch of spinal nerve C6, C7, C8, T1 and T2 or C8 or C8 and T1 \\
Median & Ventral branch of spinal nerve C8 and T1 or C8, T1 and T2 \\
Ulnar & Ventral branch of spinal nerve C6, C7, C8, T1 and T2 or C8, T1 and T2 or C8 and T1 \\
Thoracodorsal & Ventral branch of spinal nerve C6 and C7 or C8 \\
\hline
\end{tabular}




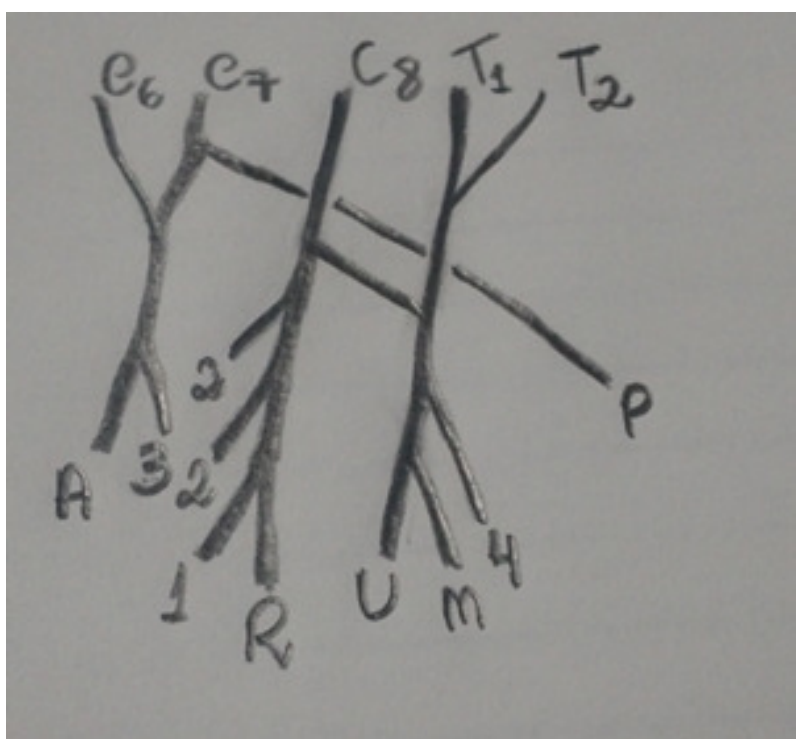

Figure 1. Schematic representation of brachial plexus of Iguana iguana iguana . C6 - sixth cervical vertebra. C7 - seventh cervical vertebra. C8 - eighth cervical vertebra. T1 - first thoracic vertebra. T2 - second thoracic vertebra. 1 - thoracodorsal nerve. 2 - cutaneous nerve. 3 - subscapular nerve. 4 coracobrachialis nerve. A - axillary nerve. $\mathrm{M}$ - median nerve. $\mathrm{P}$ - pectoral nerve. $\mathrm{R}$ - radial nerve. $\mathrm{U}$ - ulnar nerve.

\section{DISCUSSION}

The brachial plexus of these 12 iguanas comes from the ventral rami of last three cervical spinal nerves, C6, C7 and C8 and first two ventral rami of spinal thoracic nerves, $\mathrm{T} 1$ and $\mathrm{T} 2$.

The data relating to set of nerves that make up the brachial plexus facilitate access to procedures such as anesthetic block the forelimb, achieving maximum effectiveness of anesthetic agent, decreased surgical time and anesthetic dose. The scarcity of reports about the origin of brachial plexus in wild animals especially lizards, possibility of comparison to representatives of Reptila class, however, is not always reliable because of large diversity of group.

In origin of brachial plexus of iguana, compared to animals Reptila class, such as crocodiles and tortoises, there are contradictions since in crocodiles, the brachial plexus originates from ventral rami of spinal nerves 7, 8, 9, 10 and 11, which constitutes four nerve trunks and a nervous fillet (WYNEKEN, 2007; SUZUKI; HAYASHI, 2010) while in red-legged tortoises, the brachial plexus originates from ventral rami of spinal nerves 5, 6, 7, 8 and 9 (CARVALHO et al., 2011).It is expected the lack of consensus because despite belonging to the same class, have order, family and different genres, and these factors cause changes in the number of vertebrae and on-site implementation of thoracic member.
By relating the origin of brachial plexus of iguana comparing with lizards from Squamata order, there is consonance with species Uracentron azureum, Lacerda lépida, Xenosaurus grandis, Chalcides acellatus, Gekko gecko, Uroplatus fimbriatus, Tarentola annularis, Agama agama, Chalarodon madagascariensis and Sphenodon punctatus. In these species, the origin of brachial plexus corresponds to ventral branches spinal nerves 6, 7, 8, 9 and 10 (GREGORY; CAMP 1918; LÉCURU, 1968; RENOUS-LÉCURU, 1972). This correlation relates the presence of equal amounts of cervical vertebrae and consequently same site forelimb, however these species belong to different genera and families as a result of high variability, habitat interference, presence of food and predators.

However, there is unconformity related to the origin of the brachial plexus of iguana with other lizard species such as Chamaeleon verrucosus, Chamaeleon parsoni, Brookesia spectrum and Lanthanotus borneensis. In these lizards three ventral branches of the spinal nerves are the source of brachial plexus, though there is variation in location of these branches, the Lanthanotus, plexus originates in ventral branches of spinal nerves 7, 8 and 9 and Chamaeleon and Brookesia, brachial plexus corresponds to the ventral rami of spinal nerves 4, 5 and 6 (LÉCURU, 1968). This contradiction exemplifies the discrepancy in number of cervical vertebrae and the forelimb mounting location in axial skeleton. 
In the current study, there is the presence of anastomoses in ventral rami of spinal nerves to form the axillary, subscapular, cutaneous, pectoral, coracobrachialis, radial, median, ulnar, thoracodorsal nerves, which are some of main nerves for thoracic limb. This characteristic is in agreement with findings of Renous-Lécuru (1972) who found variations in composition of nerves to the brachial plexus. This variability allows the survival of strains because conditions the maintenance of species to different individuals, making the changes and adaptations to habitat.

\section{CONCLUSIONS}

The ventral rami of spinal nerves C6, C7, $\mathrm{C} 8, \mathrm{~T} 1$ and $\mathrm{T} 2$ form the brachial plexus in 12 iguanas occurring several anastomoses and greater prevalence (41.6\%) C6 to $\mathrm{T} 1$.

The main nerves observed in Iguana iguana iguana are axillary, subscapular, cutaneous, pectoral, coracobrachialis, radial, median, ulnar, thoracodorsal nerves.

RESUMO: Esse trabalho tem como objetivo descrever a origem do plexo braquial de 12 iguanas, machos e fêmeas, doados mortos pelo Centro de Triagem de Animais Silvestres e Companhia Independente de Polícia Rodoviária e Ambiental - Araguaína - Tocantins, ao Laboratório de Anatomia da Universidade Federal do Tocantins, campus de Araguaína. Fixou-se os animais com injeções intramusculares de solução aquosa de formalina a 10\%. Realizou-se uma incisão paralela a linha mediana dorsal desde o crânio até a região caudal das costelas. Retirou toda a musculatura epiaxial, oito costelas, o periósteo, expondo e individualizando os ramos ventrais dos nervos espinhais que compõem o plexo braquial. Os ramos ventrais dos nervos espinhais C6, C7, C8, T1 e T2 formam o plexo braquial nas 12 iguanas. Em 41,6\% dos casos, os ramos envolvidos foram C6, C7, C8 e T1; em 33,4\%, os ramos C6, C7, C8, T1 e T2; em 16,6 \% os ramos C7, C8, T1 e T2 e em 8,4\%, os ramos C7, C8 e T1. Dos ramos ventrais C7, C8 e T1 formavam três troncos e C6 e T2, quando presentes, consistiam de filetes nervosos. Houve variação no número de vértebras na Iguana iguana iguana, que provocaram oscilações nas anastomoses que constituem os nervos do plexo braquial nas iguanas. Os nervos axillar, subscapular, cutâneo, peitoral, coracobraquial, radial, mediano, ulnar e toracodorsal são os principais nervos que constituem o plexo braquial nas iguanas.

PALAVRAS CHAVE: Iguana iguana iguana. Membro torácico. Nervo espinhal. Sistema nervoso periférico.

\section{REFERENCES}

ANDRADE, C. A. F. Bicho da vez: Iguana verde (Iguana iguana). Museu de Zoologia João Moojen. Universidade Federal de Viçosa. v. 6, 2009. http://www.museudezoologia.ufv.br/bichodavez/edicao06.pdf.

ARAÚJO, E. B.; LIMA, A. R.; PINHEIRO, L. L.; MUNIZ, J. A. P. C.; IMBELONI, A.; BRANCO, E. Origem e distribuição do plexo braquial em Saimiri sciureus. Pesquisa Veterinária Brasileira, Seropédica, Rio de Janeiro, v. 32, n. 12, p. 1351-1354, 2012.

BAUMEL, J. J. Sistema nervoso das aves. In: GETTY, R. Anatomia dos animais domésticos. 5. ed. Rio de Janeiro:Guanabara-Koogan, 1986, p. 1890-1930.

BAUMEL, J. J.; KING, A. S.; BREAZILE, J. E.; EVANS, H. E.; BERGE, J. C. V.. Handbook of Avian Anatomy: Nomina Anatomica Avium. 2. ed. Cambridge: Nuttal Ornithological Society, 1993. 779 p.

BENÍCIO, R. A.; MESQUITA, P. C. M. D.; CAVALCANTE, V. H. G. L.; FONSECA, M. G. Répteis de uma região de ecótono no Estado do Piauí, Nordeste do Brasil. Gaia Scientia, João Pessoa, v. 9, n. 1, p. 95-100, 2015.

CARVALHO, R. C.; SOUSA, A. L.; OLIVEIRA, S. C. R.; PINTO, A. C. B. C. F.; FONTENELLE, J. H.; CORTOPASSI, S. R. G. Morphology and topographic anatomy of the spinal cord of the red-footed tortoise (Geochelone carbonaria Spix, 1824). Pesquisa Veterinária Brasileira, Seropédica, Rio de Janeiro 31, p. 47$52,2011$. 
CERVIK-DEMIRKAN, A. Anatomical structure of the brachial plexus in the Merlin (Falco columbarius). Anatomia, Histologia, Embryologia, Massachsetts, v. 43, p. 31-35, 2014.

CRUZ, G. A. M.; ADAMI, M.; ALMEIDA, A. E. F. S.; SILVA, E. A. A. C.; FARIA, M. M. M. D.; PINTO, M. G. F.; SILVA, R. D. G. Características anatômicas do plexo braquial de tamanduá-mirim (Tamandua tetradactyla, Linnaeus, 1758). Revista Brasileira Saúde Produção Animal, Salvador, v. 13, n. 3, p. 712-719, 2012. http://www.rbspa.ufba.br.

GREGORY, W. K.; CAMP, C. L. Studies in comparative myology and osteology. Bulletin American Museum of Natural History, New York, v. 38, n. 3, p.447-610, 1918.

KOIZUMI, M.; SAKAI, T. On the morphology of the brachial plexus of the platypus (Ornithorhynchus anatinus) and the echidna (Tachygolossus aculeatus). Jornal of Anatomy, Massachsetts, v. 190, p. 447-455, 1997.

LÉCURU, S. Constitution du plexus brachial des Lacertiliens (Reptilia). Journal für Hirnforschung, Berlin, v. 10, f. 6, p. 499-513, 1968.

YOSHITOMI, S.; KAWASHIMA, T.; MURAKAMI, K.; TAKAYANAGI, M.; INOUE, Y.; AOYAGI, R.; SATO, F. Anatomical architecture of the brachial plexus in the common hippopotamus (Hippopotamus amphibius) with special reference to the derivation and course of its unique branches. Anatomia, Histologia, Embryologia, Massachsetts. v. 41, p. 280-285, 2012.

MARTINS, M.; MOLINA, F. B. Répteis. Panorama geral dos répteis ameaçados do Brasil. In: eds: MACHADO, A. B. M.; DRUMMOND, G. M.; PAGLIA, A. P. et al. Livro Vermelho da Fauna Brasileira Ameaçada de Extinção. v. 1, p. 327- 334. 1ํe. Fundação Biodiversitas. Ministério do Meio Ambiente. 2008. http://eco.ib.usp.br/labvert/texto-repteis-livro-vermelho.pdf.

MEERS, M. B. Crocodylian forelimb musculature and its relevance to Archosauria. The Anatomical Record, Salt Lake City, v. 274, n. 2, p. 891-916, 2003. https://doi.org/10.1002/ar.a.10097

RENOUS-LÉCURU, S. Discussion sur les variations du plexus brachial dez deux Lacertiliens: Agama agama Linné (Agamidés) et Chalarodon madagascariensis Peters (Iguanidés). Gegenbaurs Morphologisches Jahrbuch, Leipzig, v. 118, n. 1S, p. 81-104, 1972.

SCAVONE, A. R. F.; MACHADO, M. R. F.; GUIMARÃES, G. C.; OLIVEIRA, F. S.; GERBASI, S. H. Análise da origem e distribuição dos nervos periféricos do plexo braquial da paca (Agouti paca, Linnaeus, 1766). Ciência Animal Brasileira, Goiânia, v. 9, n. 4, p. 1046-1055, 2008.

SOUZA, K.; COELHO, R. D. F.; PIMENTEL SOBRINHO, C.; NASCIMENTO, J. P. B.; GOGLIATH, M.; RIBEIRO, L. B. Fauna de lagartos de hábitats de Caatinga do Campus Ciências Agrárias da Universidade Federal do Vale do São Francisco, Petrolina-Pe, Brasil. Revista Brasileira de Zoociências, Juiz de Fora, v. 15, n. 1,2,3, p. 253-265, 2013.

SUZUKI, D.; HAYASHI, S. Myology of crocodiles II: Pectoral girdle and forelimb. The Palaeontological Society of Japan, Tokyo, n. 87, p. 83-102, 2010.

WYNEKEN, J. Reptilian Neurology: Anatomy and Function. Veterinary Clinics of North America: Exotic Animal Practice, Philadelphia, v. 10, p. 837-853, 2007 https://doi.org/10.1016/j.cvex.2007.05.004 